UDC 327(560)

DOI: https://doi.org/10.18485/iipe_ria.2021.72.1181.1

Biblid 0543-3657, 72 (2021)

Vol. LXXII, No. 1181, pp. 5-22

Original paper

\title{
MAKING SENSE OF TURKISH FOREIGN POLICY: WHAT CAN INTERNATIONAL RELATIONS THEORY OFFER?
}

\author{
Umut UZER $^{1}$
}

\begin{abstract}
State identity not only defines how elite decision-makers, as well as the informed public, identify their governmental affiliation but also informs the actions of the policymakers in the conduct of their foreign policy. There are numerous studies dealing with the role of ideas, identity and norms in international relations by scholars belonging to the constructivist school of thought in International Relations Theory. This study purports to offer such a constructivist analysis of Turkish foreign policy behaviour based on the gradual change of Kemalist state identity from a secular Western-oriented identity to that of a religious-based affiliation under the current Justice and Development Party (2002-2020). While realist variables are significant for explicating major events of Republican Turkey, such as its alignment with the United States after World War II, Turkey's policy decisions towards Cyprus and the Turkic republics of the former Soviet Union cannot be explained by purely materialist factors. For an adequate understanding of these policies, we need to resort to analytical eclecticism employing both realist and constructivist variables for a more sophisticated analysis of Turkey's foreign relations. When it comes to the JDP government, however, constructivist variables trump realist explanations as Turkish foreign policy, especially in the Middle East, has been clouded and shaped by an Islamically-framed Weltanschauung.

Key words: Constructivism, state identity, Turkish foreign policy, Kemalism, NeoOttomanism.
\end{abstract}

\section{INTRODUCTION}

Turkish foreign policy is in dire need of theoretical explications as most of the work on that topic involves empirical studies, which are valuable in mastering the details that would be relevant for our understanding of Turkish foreign policy behaviour while they lack the theoretical depth, which international theories can

\footnotetext{
${ }^{1}$ Associate Professor, Department of Humanities and Social Sciences, Istanbul Technical University, Turkey. Email: uuzer@itu.edu.tr
} 
offer. In other words, studies that employ International Relations Theory are few, which makes such an approach significant for both academic and policy considerations. ${ }^{2}$ This article argues that IR theory offers multiple venues for a better understanding of Turkish foreign policy behaviour. Focusing on Kemalist foreign policy, particularly the 1923-1938 era and the post-Kemalist foreign policy of the Justice and Development Party, especially from 2006 until 2020, this study argues that a constructivist approach to foreign policy behaviour is particularly significant in understanding the policies of the current Turkish government.

The main puzzle is whether changes in the ideas of the decision-makers of a particular country result in diverging foreign policy outcomes when compared with previous eras. Therefore, some of the research questions include: What were the characteristics of the foreign policy of Mustafa Kemal Atatürk (i.e., Kemalist foreign policy); what ideas and identities informed Kemalist foreign policy; was it really as peaceful as has been argued by the advocates of Atatürk; what has changed under the Justice and Development Party; what are the ideas and identities of the new ruling party of Turkey from 2002 onward? Can realist or constructivist variables offer a better understanding of Turkish foreign policy behaviour as far as the two cases are concerned?

In order to tackle and unpack these questions and concerns, this article starts with a literature review of IR theory to employ it as an intellectual tool for answering them. Then the methodology and case studies will be laid out. An analysis of Turkish foreign policy of Atatürk, and the ideational components of Kemalism, which guide foreign policy behaviour, as well as realist elements such as survival and power, are essential to clarify the significance of constructivism and realism for the Atatürk era. On the other hand, ideational components of the Justice and Development party's ruling cadres, especially that of Recep Tayyip Erdoğan, are paramount to comprehend the change in foreign policy behaviour of his government. It is the contention of this study that ideological elements trump realpolitik calculations of state behaviour under this government, especially when it comes to the Middle East. Moreover, such considerations are not confined to the JDP's approach to the region and are applicable to other areas of the world as well, but that would be beyond the scope of this article. Suffice it to say that, a similar study can be undertaken vis-à-vis Turkey's relations with the European Union as a discourse analysis of President Erdoğan's speeches would reveal that he perceives European and Turkish/ Islamic civilizations to be distinct and separate. (Sabah 2020, for a contradictory statement see: NTV 2021). ${ }^{3}$ Additionally, he perceives the Islamic

\footnotetext{
${ }^{2}$ Of course, it could be argued that policymakers do not take theoretical considerations into account. See: Avey and Desch 2014.

${ }^{3}$ Though we can also find a few positive characterizations by Erdoğan as he uttered the words "We see Turkey's future in Europe”, which was quite surprising after many years of hostile haranguing
} 
and Ottoman heritage to be superior to the Western world, as he presents the former as more humane and egalitarian as opposed to the European worldview, which is more rigid and discriminatory towards non-European peoples.

In other words, there is an East-West dichotomy among the conservative rulers of Turkey, a state of affairs, which can be characterized as Occidentalism that essentializes the West and, in fact, contains elements of hostility towards the Western World. Occidentalism is, in fact, the mirror image of Orientalism by which the Western powers aimed to dominate the Orient using academic knowledge (Metin 2020) and containing a simplistic depiction of the East. Therefore, there are plenty of approaches in different parts of the world that easily generalize without fully grasping other peoples. Having said all that, regardless of their claims of authenticity as far as culture is concerned, the JDP government is quite comfortable with capitalist economics, including international trade. Discussing that would of course constitute a whole different article.

In sum, this framework offers a theoretical understanding of foreign policy and how IR theory can explain changing foreign policy behaviour, particularly regarding Turkey's approach to Palestine and Israel. The above discussion about the differentiation between the Islamic world and the West, of which Palestine occupies a central place, is closely connected with issues of identity, about which constructivism has a lot to offer.

\section{IS IR THEORY RELEVANT FOR EMPIRICAL ANALYSIS?}

Constructivism, according to Nicholas Onuf, starts with deeds, then involves actions followed by the words uttered. Accordingly, "people and societies construct and constitute each other" and hence the "world is a social construction" consisting of both material and social realities (Onuf 1989, 36, 39, 40). As opposed to realism, which has a materialist ontology, constructivism has an ideational ontology (Wendt 1999, 372) with a focus on shared ideas, identity, and norms. While not denying the existence of the material world, constructivists such as Alexander Wendt, give significance to the meanings we attribute to the material world as regards weapons, our own selves or threat perception. In other words, it is very much the ideas that constitute power and the material world out there (Wendt 1999, 90, 96). Consequently, a country's self-definition would have drastic foreign policy repercussions if that country is ready to consistently follow up its declared principles.

Identity is defined by Samuel Huntington as "a sense of self" or "selfconsciousness that I or we possess distinct qualities as an entity that differentiates"

against the EU. He made these remarks during his meeting with the president of the European Commission Ursula von der Leyen. See: NTV 2021. 
us from others and conferring "distinctiveness" to the nation or any other collective (Huntington 2004, 21). It should also be pointed out that the construction of national identities is a social process as state as well as national identities always entail an outside or inside enemy or simply an Other (Barnett 1999, 9). If we need an Other to be able to define ourselves, our own definition is usually self-serving as noble, heroic and peace-loving, whereas others are usually hostile, cruel and aggressive. Of course, that perception would most likely not be shared by our adversaries or rivals.

The most consequential variables for this study are state and national identity which might or might not overlap. The identity of a state refers to "who or what actors are", while at the same time state interests are related to the desires of the state actors (Wendt 1999, 231). Changing state identities or accepting new norms of peaceful coexistence or re-definition of state identities as "trading states" undoubtedly had a massive influence on the foreign policy behaviours of Germany and Japan after WWII (Katzenstein 1996, 55-60). Needless to say, realist factors such as warfare led to this result, but a change in the material situation of Japan and Germany also caused the revision of the mental map of the German and Japanese decision-makers, making war unthinkable in the conduct of their international relations.

By discussing and interpreting the role of ideas and identities in world politics in general and specific regions or countries in particular, it is possible to offer fresh analyses of foreign policy behaviour. For instance, focusing on the relations between Arab countries, purely strategic explanations are inadequate since they did not simply balance against each other, but rather resorted to the protection of the "norms of Arabism", which defined acceptable behaviour for all Arab states. The Egyptian President Gamal Abdel Nasser's main source of strength came from his ideational framework of Arabism influencing the Arab masses well beyond Egypt's boundaries (Barnett 1998, 2, 7). In other words, competition for the soul of the Arab world was not only based on material resources, but also on the ideational mindset of the Arab masses and the literati.

While there are numerous empirical studies of Turkish foreign policy (Hale 2002; Robins 2003), there is a gap in the literature when it comes to theoretically grounded research ${ }^{4}$ analysing Turkish foreign policy behaviour. Therefore, this article offers a framework of analysis to use IR theory in explicating Kemalist and post-Kemalist Turkey as far as its foreign policy behaviour is concerned. For the former case, a combination of realist and constructivist variables are offered for comprehending Turkish foreign policy. The latter case, on the other hand, is

\footnotetext{
${ }^{4}$ The few exceptions include: Uzer 2011 and Bozdağlığlu 2003.
} 
adequately analysed with ideational factors such as religion and identity and their impact on policy implementation.

The main hypotheses of this study entail whether ideologically motivated political parties moderate their discourse when they come to power, when does ideology trump practical realpolitik considerations, and whether the rational calculation of state interests and objectives of regional hegemony are behind what appears as ideologically-driven policies? The case of Turkey between 1920-1938 and 2002-2020 periods, which I label as Kemalist and post-Kemalist eras respectively, are put under scrutiny employing the tools of International Relations Theory. Discourse, as well as specific policy decisions, are presented to decipher Turkish foreign policy behaviour during these two different periods.

\section{"PEACE AT HOME, PEACE IN THE WORLD?" WAS KEMALIST TURKEY ALL THAT PEACEFUL?}

The major transformation of the Ottoman Empire from a multinational empire into a republican pro-Western Turkish nation-state was one of the monumental events in the Balkans-Caucasus-Middle East strategic triangle. This was no less than a civilizational change of the state and national identity of the Turkish polity from that of an Islamic-dynastic structure to a modern-secular Turkish state. In many ways, a new Turk was to emerge from the ashes of the Ottoman Empire, which was imbued with the instruments of science having reached the level of contemporary civilization, meaning that of Europe. Nonetheless, the new Turk was to become Western not only in his/her thought, but also in manners, outfit, and taste. At the same time, pre-Ottoman Turkish culture was researched to supersede the now-defunct Ottoman traditions. While many elements of the new national culture were based on the negation of the old Ottoman culture, a complete rupture would not be possible as almost all the founders of modern Turkey were, until recently, Ottoman officers, bureaucrats and intelligentsia.

Throughout centuries, Turkish national consciousness was at best tenuous as the majority of the people of Turkey did not have a clear Turkish identity but preferred local or religious identities. Consequently, Turkish nationalism emerged at the end of the nineteenth century but was confined, predominantly to a limited number of intellectuals and parts of the reading public (Uzer 2016, 22-23). With the establishment of the Republic of Turkey in 1923, Turkish nationalism became part of the official ideology, namely Kemalism, of which nationalism was one of its six arrows, ${ }^{5}$ that is the main principles of the state ideology. While there was a

\footnotetext{
${ }^{5}$ The Six Arrows did not immediately appear in 1923 but rather evolved throughout the Kemalist era, finally entering the constitution in 1937. Nationalism, however, was clearly the main catalyst of Atatürk's thought.
} 
passionate and exuberant propagation of Turkish nationalism, there were limitations to its content as Atatürk and others did not want to antagonize the Soviet Union in which numerous Turkic peoples resided.

Therefore, the founder of modern Turkey, Mustafa Kemal Atatürk (1881-1938), was quite clear on his rejection of pan-Turkism and Pan-Islamism in his long sixday speech during the Second Republican People's Party (CHP-Cumhuriyet Halk Partisi) convention in 1927, known in Turkish historiography as the Speech (Nutuk). Atatürk pointed out that "a national policy within the borders of the Republic of Turkey" would be the policy preference for Republican Turkey (Atatürk 1963, 436). In other words, as the new Turkey was established on the negation of the Ottoman Empire, a new outlook based on Atatürk's statement "Peace at Home, Peace in the World" would guide its foreign policy together with a Western vocation (Oran 2002, 20-21) and an emphasis on international law (Bozer 1990, 20). According to one constructivist analysis of Turkish foreign policy, this pro-Western stance emanates from the Western identity intrinsic to Kemalism (Bozdağloğlu 2003, 7-9) by making the country part of the Western civilization, which was one of the paramount goals of Atatürk. While this framework offers a significant contribution to a theoretical analysis of Turkish foreign policy, which is rare as mentioned in the introduction of this article, it only presents one side of the coin. In other words, nationalism which is one of the six arrows of Kemalism also offers a guideline for policymakers as far as interest in the affairs of External Turks is concerned. The concept "External Turks" refers to people of Turkish ethnicity living in the vicinity of modern Turkey in places such as Western Thrace or Syria and Iraq. Moreover, the varying degrees of involvement in Hatay, Cyprus and Nagorno-Karabagh can be better understood by utilizing the Turkish element in Turkey's state identity (Uzer 2011). To clarify, Turkey's involvement in the above-mentioned regions cannot be explained by purely strategic motivations since, without the existence of Turks in distress, cross-border involvement would not have been justified in the eyes of the Turkish public. Moreover, it should be pointed out that there were varying degrees of involvement in these three cases, from outright annexation of Hatay in 1939, military operations in Cyprus in 1974 to public statements of support by politicians in Turkey in the case of Nagorno-Karabakh throughout the 1990s, which incidentally has continued up until now, particularly visible in the liberation of significant parts of occupied Karabakh by Azerbaijani forces in September-November 2020.

Going back to discussing Kemalist foreign policy, it would be in order to point out that the multidimensional character of Atatürk's foreign policy resulted in the establishment of a number of regional cooperation schemes, such as the Balkan Pact and the Sadabad Pact signed in the 1930s with its neighbours.

In 1930, the leaders of Albania, Bulgaria, Greece, Romania, Turkey and Yugoslavia met at a summit in Athens, where they discussed multiple levels of cooperation between their respective countries. Four years later, the Balkan Pact 
was signed in the Greek capital by Greece, Romania, Turkey and Yugoslavia, assuring each other that the territorial integrity of all the signatories would be protected and that endeavuors of Bulgaria to expand its territories would be checked. It should be noted that close relations between Greece and Turkey (Akşin 1991, 261-266, 270-271) were particularly significant as the two countries were involved in warfare in the early 1920s.

However, the Balkan Pact did not meet the security needs of Greece and Yugoslavia when the former was attacked by Italy in 1940 and the latter occupied by Germany in 1941 as both countries demanded help from Turkey within the parameters of the Balkan Pact. Turkey had a different understanding of the Pact as it argued that it was predominantly concerned with Bulgaria and not Italy (Barlas and Vlasic 2016, 1011). Needless to say, it was well beyond Turkey's power to resist the German or Italian occupation of Greece and Yugoslavia and hence it was more concerned with protecting its own territorial integrity against those expansionist states. In other words, state survival, protection of the territorial integrity of the country, and eschewing adventurist foreign policy behaviours were the basic characteristics of Kemalist foreign policy.

The Sadabad Pact, on the other hand, signed in 1937 between Afghanistan, Iran, Iraq, and Turkey in Sadabad Palace in Tehran, was a treaty of non-aggression guaranteeing all signatories to refrain from interfering in the domestic affairs of each other. Supported by the USSR and the UK, the ultimate objective of the pact, according to the Turkish Foreign Minister Tevfik Rüştü Aras, was peace (Akşin 1991, 198-200) in the region. He also characterized Kemalist foreign policy in general and these pacts in particular as part of Turkey's belief in collective security through regional cooperation (Aras 2003, 202). Furthermore, in 1932, Turkey acceded to the League of Nations, whose paramount concern was collective security against aggression, and became one of the adamant supporters of sanctions against Italy due to the latter's occupation of Ethiopia (Aykan 1994, 20) in 1935.

The fact of the matter was that recognition and affirmation of the new regime in Turkey was one of the major considerations of its leaders. Therefore, a number of bilateral treaties were signed with its neighbours in addition to those regional multilateral pacts. Earlier, in 1921, even before the establishment of the Republic of Turkey in 1923, Turkey and Afghanistan had signed a security agreement in Moscow. Turkey agreed to dispatch security personnel as well as teachers to Afghanistan and eventually established a medical school in Kabul. As a result of these friendly relations, Amanullah Khan, the ruler of Afghanistan visited Turkey in 1928 (Akşin 1991,191-194; Akbaş 2008, 314). The leaders of both countries were interested in modernizing their societies, but the Afghan experience was short-lived as the king could not stay in power for long, whereas Turkish modernization was more resilient, lasting until the early twenty-first century. 
Turkey also signed a peace and friendship treaty with its eastern neighbour Iran in 1926 resulting in that country providing aid to Turkey's counterinsurgency measures in its territories, in proximity to the Iranian border. Furthermore, the Iranian ruler Reza Shah visited Turkey in 1934, culminating in Atatürk characterizing bilateral relations as of utmost importance for both countries (Akşin 1991, 194-196).

It should be mentioned that the Sadabad Pact, as well as the Balkan Pact, were part of Turkey's opening up to its neighbours, conducting a multilateralist foreign policy and creation of a zone of peace among all the respective countries. While this is an indisputable fact, it should also be noted that there were cases when Turkey tried to recapture former territories belonging to the Ottoman Empire, especially those considered to be part of the National Pact (Misak-1 Milli) delineating its borders. The territories in question were the former province of Mosul in Iraq under the British mandate and the Sanjak of Alexandretta in Syria under the French mandate. While Turkey's efforts to regain Mosul were futile in the 1920s, Atatürk laid the groundwork for the annexation of Alexandretta and Antioch, known as Hatay in Turkish, which occurred in 1939, one year after the death of Atatürk.

Turkey has used all elements of diplomacy short of war, namely public statements, public relations, inducements to foreign powers and the like to recover Hatay from Syria under the French mandate and reunite it with the mainland. There was a strong national consensus of the masses in Turkey as the government was propagating the significance and "Turkishness" of Hatay to the people. President Atatürk was personally involved in these endeavours and successfully conducted the whole Hatay operation (Uzer 2011, 89) until his death prior to the legal unification of the area with Turkey. It would be in order to say that Turkey's push for a referendum in Hatay and then the declaration of independence of Hatay, culminating in its decision to join Turkey, would have been perceived as a policy of expansionism by a significant part of the Syrian elite and the masses. Though all measures were taken in conformity with international law, such as demands of self-determination, a plebiscite and the resolution of the parliament of Hatay to become part of Turkey, these decisions would not be seen as legitimate by significant portions of Syrian society.

The truth of the matter was that Atatürk got personally interested in Hatay during World War I, as he was one of the commanders of the Ottoman army in Syria, during which time he tried to resist any British encroachment on Alexandretta. Afterwards, France has recognized nationalist Turkey with the 1921 Ankara agreement, which stipulated that Turkish would be accepted in the special administrative unit of Alexandretta within the French mandate of Syria. Turkey's position on Hatay was expressed in Atatürk's statement "a land which belonged to the Turks for forty centuries cannot remain under enemy control" (Sanjian 1956, 379). ${ }^{6}$ Therefore,

\footnotetext{
${ }^{6}$ For Atatürk's statement, see: Tekin 1993, 118-119, 124, and Ada 2006, 51.
} 
Atatürk's determination to eventually get Hatay back was evident from the 1920s till the end of the 1930s.

Numerous public relations campaigns were instigated in the Hatay region by supporting newspapers in Latin script, adopted earlier in Turkey in 1928, opening football clubs and visits by dignitaries from Turkey to the region to keep the interrelationship between the two entities as close as possible. Furthermore, People's Houses were opened in the area to inculcate the new Kemalist creed into the inhabitants of Hatay. In 1937, Turkish soldiers moved towards the Syrian border, and Atatürk planned to visit the border areas with full fanfare but was dissuaded by his ever-cautious Prime Minister İsmet İnönü (Tekin 1993, 134-136, 147-150). The Republic of Hatay, which existed from September 1938 until July 1939, had already accepted Kemalism as its state ideology and a flag very similar to that of Turkey. In late June, the parliament of Hatay decided to become part of Turkey, which came into effect in July when Hatay was incorporated into Turkey (Uzer, 2011, 100-101) as one of its provinces. The Hatay affair demonstrates that Turkey's state identity had a strong Turkish component not only at the domestic level but also in its foreign policy. It would take strong action provided it did not jeopardize its national survival. In fact, "adventurism" was something that Turkish leaders eschewed as they perceived some of the actions of Enver Pasha, the leader of the late Ottoman Empire during World War I, as reckless, resulting in utter failure. Therefore, for Kemalist leaders, state and national survival were paramount. Yet if certain conditions were satisfied, there would be actions to rectify past injustices.

The condition of Turkish involvement in Hatay and Cyprus are discussed in detail in the book Identity and Turkish Foreign Policy, which argued that there were a number of preconditions that should be satisfied for Turkey to take a more active role in the affairs of "External Turks". The internal factors included: the perception of the dispute as a paramount national interest, "ethnic kin under oppression", "national consensus" for the necessity of involvement, whereas external factors should include a "conducive international environment" and no veto of Turkey's activism by any of the major countries in the region or the world (Uzer 2011, 86). In other words, the portrayal of the Atatürk era as peaceful is only one part of the story, as the Hatay case demonstrates that Turkey did not rule out foreign policy activism to correct, what it perceived to be, historical wrongs.

In sum, both state interests and state identities are significant in analysing Turkey's foreign policy during the rule of Atatürk. A number of pacts in its region can be understood by national security considerations while at the same time perceiving the Turkish state as peaceful, which was demonstrated in Atatürk's famous motto, can be explicated by constructivist variables such as a peaceful state identity. Similarly, the policies towards Hatay can be best unpacked by both constructivist factors, such as the Turkish characteristic of the region according to Turkish decision-makers, as well as the strategic location of Hatay, although the 
latter has not been as much emphasized by Turkish politicians. Having said all that, however, this balance of the materialist and ideational variables has radically changed in Turkey during the twenty-first century, especially regarding its policy in the Middle East.

\section{A POST-KEMALIST TURKEY 7}

After almost 80 years of Kemalism as the dominant state ideology of Turkey, the advent of the Justice and Development Party (JDP) to power in 2002 meant a gradual change of the state identity of the country from that of Kemalism into a more eclectic mindset without however explicitly rejecting Atatürk. Hailing from the Islamist National Outlook Movement (Milli Görüss), the cadres of JDP in its initial years refrained from using extremist discourse and presented itself as a conservative political party, similar to Christian Democrats (Duran 2008, 98) in Europe.

Admittedly, there were cracks in the Kemalist shell as a number of rival identities have emerged in the 1980s. Kurdish, Alevi and Islamic affiliations became more visible in the 1980s as the country has opened up to the West and a consumerist economy was supported by the Motherland Party under the leadership of Turgut Özal who became Prime Minister in 1983. This was also the period of the rise of "Anatolian tigers" - provincial Anatolian cities that had economically developed as a result of the export-led growth supported by the government and became bastions of conservatism both at the centre and the periphery. The pro-Western orientation was still solid under Özal whereas, under the JDP government, pro-EU policies were used more as tactical tools to tame the military and break the hegemony of the foreign policy establishment which was quite hawkish on a number of issues, most important of which was Cyprus.

It is always appealing to find historical turning points, and one such episode was the unofficial visit by Khaled Mashal, one of the leaders of Hamas to Ankara in 2006, which was labelled as "a policy shift" by Soner Çağaptay (Çağaptay 2006) of the Washington Institute for Near East Policy, a think tank located in Washington D.C. This visit was spearheaded by Ahmet Davutoğlu, who was the foreign policy advisor at the time and had orchestrated the visit, despite strong objections from the Foreign Ministry (Hürriyet 2006). It cannot be stressed enough that Turkey's turn towards the Middle East, and more importantly to the Islamic world, was initiated and intellectualized by Ahmet Davutoğlu (Janković, 2016), who was one of the few members of JDP who had any understanding of foreign policy. Having said that, however, Davutoğlu had a romantic attachment to the former Ottoman Empire and lacked in-depth analysis and knowledge of the region about which he

\footnotetext{
${ }^{7}$ For post-Kemalism, see Aytürk 2015.
} 
pontificated. Of course, such slogans also reverberated with the Islamically oriented leaders of the JDP, most notably with prime minister Recep Tayyip Erdoğan (20032014), who was elected as president in 2014, whereas Davutoğlu became prime minister in 2014 and served until 2016. The two figures later had a falling out as a result of which Davutoğlu established the Future Party (Gelecek Partisi) in 2019.

Coupled with Turkey's domestic policy of Islamization, which included a campaign to build mosques in central places such as Taksim Square (Hansen and Behrendt 2017) in Istanbul or on hilltops overlooking the city such as Çamlica Hill (Daily Sabah 2019a), as well as an unofficial declaration of warfare against alcohol by raising taxes on liquor and turning a significant number of regular elementary and secondary schools into religious İmam-Hatip Schools (Arslan 2019), and opening new schools, the policy ramifications of all these developments were quite drastic. In fact, the government was praised by the Islamist newspaper $A$ kit for having opened 4,000 such schools (Akit 2019), and this domestic Islamization also spilled over to its foreign relations as policy change was also quite radical, especially regarding the Middle East.

As discussed in the previous section, multilateralism has been one of the key tenets of Turkish foreign policy. Under the JDP leadership, however, Turkey has undertaken a more unilateral foreign policy and has presented the Palestine question in general and the Jerusalem dispute, in particular, as a matter of national concern. This can be explained by the change of the state identity from that of a Turkish secular character into a Muslim and pro-Ottoman affiliation. Officially, however, Kemalism remains the state ideology, and the secular nature of the Turkish legal system remains intact.

Having said that, however, the statements of Recep Tayyip Erdogan, "glorifying" the Ottoman Empire and attacking the early republican regime, while usually refraining from directly criticizing Atatürk by name, makes it evident that there are a counter-narrative and an attempt to create a new Turkey (Uzer 2018, 346). Indicative of feeling alienated from national holidays initiated by Atatürk and a desire to express sympathies towards the Ottoman Empire, the president on 10 November 2019, on the very day of commemoration of Atatürk's death, defended the literacy rate and arms industry under the Ottoman Empire rejecting those claiming that the Ottoman state was deficient in those areas. "Literacy rate vanished" with the change of the alphabet from Arabic to Latin (Yeniçağ 2019) in 1928, according to the president. Regardless of the veracity of these points, what is crucial is his desire to defend the Ottomans even on a day commemorating the death of Atatürk.

Moreover, his statements on the same day to the effect that Atatürk opened the parliament as an Ottoman officer and in the name of the Ottoman state (Erdoğan 2019) seems like an effort to appropriate both the Ottoman Empire and Atatürk, as well as the Turkish state tradition at the same time. His feelings of 
revulsion against those who criticize the Ottoman Empire led him to defend it and set the record straight, demonstrating where his loyalties lie.

Moving on from a discursive perspective to the policies of the JDP government, the most evident policy emanating from a Muslim and Ottoman identity is conducted towards Palestine. In the first years of the government, the JDP continued the balanced approach towards Israel and Palestine of the previous governments, being an honest broker which has been continuing over the last past decades. While the pendulum usually swung towards Palestinians most of the time, especially during the 1990s, Turkey and Israel established amicable and strategic relations.

The Justice and Development Party leadership tried to keep this balance by visiting Israel, as prime minister Erdoğan did in 2005 (TMFA 2020), as well as by undertaking an active role in peacemaking between Syria and Israel. However, as Israel's clashes with the Palestinians in Gaza in 2008-2009, 2012 and 2014 (Marks 2018) erupted from time to time, Turkey's relations were indexed to the situation in Palestine as it has become a national issue for the JDP government and particularly Recep Tayyip Erdoğan. While previous secular governments have also expressed sympathies towards the Palestinians, pro-Palestine policies and statements have reached much higher level, to such an extent that the balance has been upset, now tilting totally towards the Hamas administration in the Gaza Strip.

In 2012, an honorary doctorate was bestowed upon Erdoğan by the Palestinian al-Quds (Jerusalem) University, which is located in Abu Dis, just 4 kilometres outside the city of Jerusalem and separated from the city by the wall Israel had built. ${ }^{8}$ At the ceremony, he clearly demonstrated his criticisms of Israel and even downplayed the importance of Israel by pointing out that Turkey would continue the policies of Sultan Abdülhamid II (1876-1909), which were based on the protection of the Islamic character of the city as well as the region. He also accused the Israeli government of violating the tenets of the Torah as they paid no attention to human life (IHA 2012). This was not an isolated incident since Turkey pulled its ambassador from Israel due to the conflict following the American recognition of Jerusalem as the capital of the State of Israel in 2017 (Landler 2017) and the eventual move of its embassy from Tel Aviv in 2018 (BBC Nens 2019) to Jerusalem. As a reaction to clashes on the Gaza border between the Palestinians and Israelis emanating from these decisions, Turkey asked the Israeli ambassador Eitan Naeh to return to Israel, without having declared him a persona non grata and had recalled its ambassador to Tel Aviv Kemal Ökem back to Turkey (CNNTürk 2018). This is indicative of the fact that Turkey's position is not only based on posturing or mere talk, but genuine support for the Palestinian issue making it a national matter.

${ }^{8}$ The ceremony was held in Turkey, see: Quillen 2018. 
Turkey was adamant that America's decision was a provocation but interestingly seemed to be more furious towards Israel than the United States (Anatolian Agency 2018). Erdoğan called Jerusalem "our redline" on numerous occasions throughout 2018, emphasizing the centrality of the city for the Islamic world but also adding that it was a humanitarian issue concerning the entire world (Gazete Vatan 2018).

At the United Nations General Assembly plenary session on 24 September 2019, President Erdoğan called for global justice for refugees all around the world and demanded upholding international law, especially pertaining to Palestine (Daily Sabah 2019b). He showed a map popular on internet sites demonstrating the shrinkage of "Palestine" and expansion of "Israel" throughout the twentieth century to the present day. Of course, he was referring to the UN Partition Plan of 1947 and the territory the current Palestinian Authority controls. He asked where the precise boundaries of Israel were located and presented himself once again as the defender of the underdog and the oppressed. He repeated his slogan "World is greater than Five" (Haber Türk 2019) as a criticism of the five permanent members of the UN Security Council.

In sum, Turkey has become more royalist than the king as far as the Palestinian issue is concerned, being more supportive of the Palestinians than most Arab countries at a time when a number of Gulf countries, including the United Arab Emirates and Bahrain under the Abraham Accords (2020), have decided to normalize their relations with the Jewish state, most likely to be followed by other Arab states. Given that Turkey has not broken off diplomatic relations with Israel, since 2018 the respective ambassadors of Turkey and Israel in Tel Aviv and Ankara are back in their home countries, amounting to a de facto downgrading of their liaisons. Making Palestine a Turkish issue cannot but be explained by affinities of religion and history hence they are part and parcel of constructivism in international relations theory.

\section{CONCLUSION: RIVAL IDENTITIES OF TURKEY}

With the rise of an ideologically motivated political party to power in Turkey and its consolidation of power domestically, it resorted back to identity politics and devised a foreign policy based on the Muslim and Ottoman identity of Turkey. Turkey's fixation on Palestine cannot be explained by realist variables as it was not a matter of state interests or power maximization, unless there is a plan for leadership of the Muslim world by using the Palestinian card as a tool for such an objective. Nonetheless, there is no evidence of such a well-thought rational plan, but rather sentiments and ideological concerns seem to have trumped over realpolitik considerations. 
Consequently, the Muslim identity of Turkey has consolidated itself at the governmental level after 19 years of JDP rule as they have created a new hegemony and a new elite. Therefore, the Islamic state identity, despite the continued official secularism of the legal and constitutional system, allows for a politics of Islam aiming to protect the world-wide Islamic community- umma in Arabic and ümmet in Turkish. Going hand in hand with the Islamic identity, there is also the Ottoman identity reincarnated as neo-Ottomanism with particular concern towards the Islamic world, including Bosnia, Kosovo, and other Muslims on the former territory of the Ottoman Empire. In many ways, the Islamic and Ottoman identities overlap. While there is no overt rejection of the Turkish identity, there has been a deemphasis of the Turkish world, and the Western identity of Kemalism with its attachment to Europe has also weakened partially due to the European Union's and the United States' diverging policies vis-a-vis Turkey. At the end of the day, there is a new Turkey at the governmental level with a new state identity, which has wideranging repercussions for its foreign policy resulting in more unilateralist and activist behaviour in its region. Whether such a policy is commensurate with the material capabilities of Turkey is a whole different matter.

\section{REFERENCES}

Ada, Serhan. 2006. Türk-Fransız Iliş̧kilerinde Hatay Sorunu: 1918-1939. Istanbul: Bilgi Üniversitesi Yayınlar1.

Akbaş, İsmail. 2008. “Afgan Kralı Emanullah Han'nn Türkiye Gezisi”. Çağdaş Türkìye Taribi Arasttrmalar Dergisi 7 (16-17): 311-333.

Akit. 2019. "İHL'lerin reisi Erdoğan", March 6. https://www.yeniakit.com.tr/ haber/ihllerin-reisi-erdogan-642928.html

Akşin, Abtülahat. 1991. Atatürk'ün Dış Politika İlkeleri ve Diplomasisi. Ankara: Türk Tarih Kurumu Yayinları.

Anatolian Agency. 2018. "Türkiye ABD'nin Kudüs kararına tepki için ayakta”, May 15. https://www.aa.com.tr/tr/muslumanlarin-kirmizi-cizgisi-kudus/turkiyeabdnin-kudus-kararina-tepki-icin-ayakta/1146306

Aras, Tevfik Rüsstü. 2003. Atatürk'ün Dış Politikası. Istanbul: Kaynak.

Atatürk, Kemal. 1963. Nutuk. Istanbul: Milli Eğitim Basımevi.

Avey, Paul and Michael Desch. 2014. "What Do Policymakers Want From Us? Results of a Survey of Current and Former Senior National Security Decision Makers". International Studies Quarterly 58 (2): 227-246.

Aykan, Mahmut Bali. 1994. Turkey's Role in the Organization of the Islamic Conference, 1960-1992: The Nature of Deviation from the Kemalist Heritage. New York: Vantage Press. 
Aytürk, İlker. 2015. “Post-post Kemalizm: Yeni bir Paradigmayı beklerken”. Birikim 319: 34-47.

Barlas, Dilek and Andelko Vlasic. 2016. "The Balkan Entente in Turkish-Yugoslav relations (1934-41): the Yugoslav perspective". Middle Eastern Studies 52 (6): 1011-1024.

Barnett, Michael. 1998. Norms of Arabism: Negotiations in Regional Order. New York: Columbia University Press.

Barnett, Michael. 1999. "Culture, Strategy and Foreign Policy Change: Israel's Road to Oslo", European Journal of International Relations 5 (1): 5-36.

BBC News. 2019. "US consulate general in Jerusalem merges with embassy", March 04. https://www.bbc.com/news/world-middle-east-47442145

Bozdağlıŏlu, Yücel. 2003. Turkish Foreign Policy and Turkish Identity: A Constructivist Approach. New York: Routledge.

Bozer, Ali. 1990. “Turkish Foreign Policy in the Changing World”. Mediterranean Quarterly 1 (3): 20-22.

Çağaptay, Soner. 2006. Hamas Visits Ankara: The AKP Shifts Turkey's Role in the Middle East. Washington: Washington Institute for Near East Policy.

CNNTürk. 2018. "İsrail'in Ankara Büyükelçisi ülkesine böyle döndü”, May 16, https://www.cnnturk.com/turkiye/israilin-ankara-buyukelcisi-ulkesine-boyledondu

Daily Sabah. 2019a. "Erdoğan inaugurates Turkey's biggest place of worship, Grand Çamlica Mosque in Istanbul", May 03. https://www.dailysabah.com/istanbul/ 2019/05/03/erdogan-inaugurates-turkeys-biggest-place-of-worship-grandcamlica-mosque-in-istanbul

Daily Sabah. 2019b. "Erdoğan highlights global injustice, urges world to take action in UNGA speech", September 24. https://www.dailysabah.com/politics/ 2019/09/24/erdogan-highlights-global-injustice-urges-world-to-take-action-inunga-speech

Duran, Burhanettin. 2008. “The Justice and Development Party's New Politics: Steering toward conservative democracy, a revised Islamic agenda or management of new crises?". In Secular and Islamic politics in Turkey, edited by Ümit Cizre, 80-106. London: Routledge.

Erdoğan, Recep Tayyip. 2019. “10 Kasım Atatük’ü Anma töreninde yaptıkları konuşma”, TCBB, November 10. https://www.tccb.gov.tr/konusmalar/353/ 112502/10-kasim-ataturk-u-anma-toreninde-yaptiklari-konusma

Gazete Vatan. 2018. "Cumhurbaşkanı Erdoğan: Kudüs bizim kırmızı çizgimizdir", December 14. http://www.gazetevatan.com/cumhurbaskani-erdogan-kudusbizim-1226640-siyaset/ 
Haber Türk. 2019. “Cumhurbaşkanı Erdoğan'dan BM Genel Kurulu'nda çok sert İsrail mesajlarn" September 24, https://www.haberturk.com/son-dakikacumhurbaskani-erdogan-bm-genel-kurulu-nda-konusuyor-2525073

Hale, William. 2002. Turkish Foreign Policy: 1774-2000. London: Frank Cass.

Hansen, Suzy and Norman Behrendt. 2017. "Reading Erdogan's Ambitions in Turkey's New Mosques", The New York Times Magazine, June 14. https://www.nytimes.com/2017/06/14/magazine/reading-erdogansambitions-in-turkeys-new-mosques.html

Huntington, Samuel. 2004. Who are We? The Challenges to America's National Identity. New York: Simon \& Schuster.

Hürriyet 2006. "Alttndan o ç1ktt”. February 18, http://www.hurriyet.com.tr/ gundem/altindan-o-cikti-3952035

$\dot{I} H$ A. 2012. "Erdoğan'a Filistin'den fahri doktora”, September 21, https://www.iha. com.tr/haber-erdogana-filistinden-fahri-doktora-244306/.

Janković, Slobodan. 2016. "Vectors of Turkish foreign policy: What remains of the strategy for 2023?”. Medunarodni problemi 68 (1): 7-23.

Katzenstein, Peter, ed. 1996. The Culture of National Security: Norms and Identity in World Politics. New York: Columbia University Press.

Landler, Mark. 2017. "Trump Recognizes Jerusalem as Israel's Capital and Orders U.S. Embassy to Move", The New York Times, December 06. https://www.ny times.com/2017/12/06/world/middleeast/trump-jerusalem-israel-capital.html

Marks, Julie. 2018. "Gaza: The History That Fuels the Conflict", History, August 29. https://www.history.com/news/gaza-conflict-history-israel-palestine

Metin, Abdullah. 2020. "Occidentalism: An Eastern Reply to Orientalism". Bilig: Journal of Social Sciences of the Turkic World 93: 181-202.

NTV. 2021. "Erdoğan-Von der Leyen görüşmesi: Türkiye'nin geleceğini Avrupa'da görüyoruz", January 9, https:/ / www.ntv.com.tr/dunya/erdogan-von-der-leyengorusmesi-turkiyenin-gelecegini-avrupada-goruyoruz,BtxTwWaYXk-AR2hhrOiRA

Onuf, Nicholas. 1989. World of Our Making: Rules and Rule in Social Theory and International Relations. Columbia: University of South Carolina Press.

Oran, Baskın. 2002. Türk Dış Politikast: Kurtuluş Savașindan Bugüne Olgular, Belgeler, Yorumlar. Istanbul: İletişim.

Quillen, Stephen. 2018. "Palestinians reject plans to impose Abu Dis as capital", The Arab Weekly, October 23. https://thearabweekly.com/palestinians-rejectplans-impose-abu-dis-capital

Robins, Philip. 2003. Suits and Uniforms: Turkish Foreign Policy since the Cold War. Seattle: University of Washington Press. 
Sabah. 2020. "Başkan Erdoğan'dan anlamlı paylaşım! 'Bizim medeniyetimiz, insan medeniyetidir, ilim medeniyetidir, irfan medeniyetidir, hikmet medeniyetidir", September 26, https://www.sabah.com.tr/gundem/2020/09/26/baskanerdogandan-anlamli-paylasim-bizim-medeniyetimiz-insan-medeniyetidir-ilimmedeniyetidir-irfan-medeniyetidir-hikmet-medeniyetidir

Sanjian, Avedis. 1956. "The Sanjak of Alexandretta (Hatay): Its Impact on TurkishSyrian Relations, 1939-1956”. Middle East Journal 10 (4): 379-394.

Tekin, Mehmet. 1993. Hatay Taribi. Antakya: Hatay Kültür Turizm ve Sanat Vakfi.

[TMFA] Turkish Ministry of Foreign Affairs. 2020. “Türkiye - İsrail Siyasi Illişkileri’”. http://www.mfa.gov.tr/turkiye-israil-siyasi-iliskileri.tr.mfa

Uzer, Umut. 2011. Identity and Turkish Foreign Policy: The Kemalist Influence in Cyprus and the Caucasus. London: I.B.Tauris.

Uzer, Umut. 2016. An Intellectual History of Turkish Nationalism Between Turkish Ethnicity and Islamic Identity. Salt Lake City: University of Utah Press.

Uzer, Umut. 2018. "Glorification of the Past as a Political Tool: Ottoman History in Contemporary Turkish Politics". Journal of the Middle East and Africa 9 (4): 339-357.

Wendt, Alexander. 1999. Social Theory of International Politics. Cambridge: Cambridge University Press.

Yeniçă̆. 2019. "Erdoğan, 10 Kasım'da harf inkılabını eleştirdi”, November 10. https://www.yenicaggazetesi.com.tr/erdogan-10-kasimda-harf-inkilabinielestirdi-255722h.htm

\section{RAZUMEVANJE TURSKE SPOLJNE POLITIKE: ŠTA TEORIJA MEĐUNARODNIH ODNOSA MOŽE DA PONUDI?}

Apstrakt: Državni identitet ne samo da definiše kako elitni donosioci odluka, kao i informisana javnost identifikuju ideološko usmerenje njihove vlade, već i usmerava delovanje donosilaca odluka u vođenju spoljne politike. Postoje brojne studije koje se bave ulogom ideja, identiteta i normi u međunarodnim odnosima od strane istraživača koji pripadaju konstruktivističkoj školi mišljenja u okviru teorije međunarodnih odnosa. Ova studija ima za cilj da ponudi takvu konstruktivističku analizu turskog spoljnopolitičkog ponašanja zasnovanu na postepenoj promeni kemalističkog državnog identiteta iz sekularno-zapadno orijentisanog identiteta, $\mathrm{u}$ identitet verske pripadnosti tokom vlasti vladajuće Stranke pravde i razvoja (2002-2020). Iako realističke promenljive imaju značajan udeo u objašnjavanju glavnih događaja Republike Turske, poput savezništva sa Sjedinjenim Državama nakon Drugog svetskog rata, političke odluke Turske prema Kipru i turskim republikama bivšeg Sovjetskog Saveza, one se ne mogu objasniti 
isključivo materijalističkim faktorima. Da bismo adekvatno razumeli ove politike, moramo da pribegnemo analitičkom eklekticizmu koji koristi realističke i konstruktivističke promenljive, za sofisticiraniju analizu turskih spoljnih odnosa. Kada je pak reč o vladi SPD-a, konstruktivističke promenljive nameću realističnija objašnjenja, jer je turska spoljna politika, posebno na Bliskom istoku, bila obojena i oblikovana islamskim pogledom na svet.

Ključne rečc: konstruktivizam, državni identitet, turska spoljna politika, kemalizam, neootomanizam.

received: 02.01.2021

accepted: 01.02.2021 